\title{
Je to sepse, nebo není? A je presepsin tou správnou odpovědí? - editorial
}

\author{
Martin Matějovič \\ I. interní klinika LF UK a FN Plzeň
}

Komentář k | Editorial on

Jabor A, Kubíček Z, Labanczová M et al. Presepsin: co je nutné vědět pro korektní interpretaci. Vnitř lék 2019; 65(7-8): 490-496.

Káňová M, Dobiáš R, Liszková K et al. Presepsin v diagnostice sepse. Vnitř lék 2019; 65(7-8): 497-505.

Infekční nemoci jsou celosvětově hlavní příčinou morbidity a mortality. $U$ populace pacientů starších 65 let jsou infekce častějším důvodem hospitalizace než srdeční seIhání a infarkt myokardu dohromady [1]. Sepse je hlavní př́činou smrti na infekční choroby. Každoročně postihne na světě 30 miliónů pacientů, z nichž 25-30 \% zemře [2]. Zásadním faktorem, který významně rozhoduje o celkovém výsledku, je včasnost jejího rozpoznání a bezodkladné zahájení odpovídající léčby. Stanovení správné diagnózy u mladého pacienta s horečnatým stavem, alterací vědomí a výsevem petechií obvykle nečiní potíže. Bohužel, u řady pacientů s mnohočetnými komorbiditami a souběžně probíhajícím jiným onemocněním není rozpoznání sepse zdaleka tak prímočaré. Více než 30 \% pacientů se před rozvojem septického šoku prezentuje zcela vágními, nespecifickými symptomy, zejména extrémní svalovou slabostí, malátností, zmateností či spavostí [3]. Jeden z 8 septických pacientů príijímaných na jednotku intenzivní péče nemá projevy systémové zánětové odpovědi [4]. Naopak, 1 z 5 pacientů na urgentním př́ijmu, u kterého je klinické podezření na sepsi, sepsi ve skutečnosti nemá [5]. Rozlišení mezi skutečnou infekcí a sterilní systémovou zánětovou odpovědí je častou výzvou pro klinické lékaře urgentních př́ijmů, standardních oddělení a jednotek intenzivní péče.

Není proto překvapením, že se současný výzkum usilovně snaží objevit biomarker, který by dokázal s vysokou mírou spolehlivosti potvrdit nebo vyloučit diagnózu sepse, odlišit sterilní zánětovou odpověd' od infekční, určit nezbytnou délku antimikrobiální léčby či dokonce předpovědět průběh a celkový klinický výsledek. Za posledních 10 let bylo popsáno téměř 180 různých molekul, které byly navrženy jako specifické biomarkery sepse. Jen necelých $20 \%$ z nich dospělo do fáze klinického testování a jen výjimečně se dostaly do rutinního klinického používání. Jedním z takových, do kterého jsou vkládány naděje a kterému jsou v tomto vydání Vnitřního lékařství věnovány dva články $[6,7]$, je presepsin. Presepsin, solubilní fragment CD14 (sCD14 - Cluster of Differentiation), je součást membránového glykoproteinu na monocytech a makrofázích. Ten funguje jako recep- tor pro endotoxin a endotoxin vázající proteiny. Obecně je považován za proinflamatorní molekulu, která slouží k rozpoznání patogenů a spouštění cytokinové a chemokinové odpovědi. Přesná biologická úloha však není dosud spolehlivě objasněna. Přehledný článek autorů Káňové et al čtenářưm detailně přibližuje fyziologii presepsinu, diskutuje jeho diagnostický a prognostický význam, hodnotí jeho přínos ve srovnání s konvenčními biomarkery sepse (C-reaktivní protein - CRP, prokalcitonin - PCT) a neopomíjí ani jeho limitace, především u pacientů s poruchou funkce ledvin či u imunodeficitních stavů [6]. Rychlý nástup hladin presepsinu (1-3 hod od rozvoje infekce), menší ovlivnění jeho koncentrací v pooperačních stavech nebo u rozsáhlejšího tkáňového traumatu a rychlé (do $15 \mathrm{~min}$ ) stanovení jeho koncentrace v krvi u lůžka nemocného jsou hlavními argumenty, o které autoři článku opírají své doporučení pro jeho rutinní klinické využití, včetně návrhu na kombinované použití společně s ostatními dostupnými biomarkery. Původní vědecký článek Jabora et al předkládá výsledky vyhodnocení přesnosti stanovení presepsinu, ověření jeho biologické variability u zdravých dobrovolníků a posouzení cut-off hodnot [7]. Autoři uzavírají, že analytická spolehlivost stanovení presepsinu jediným na trhu dostupným systémem je adekvátní pro klinické použití, ale varují před používáním univerzálních cut-off hodnot, podobně jako u jiných dostupných biomarkerů (CRP, PCT, IL6).

Pojd'me se společně kriticky zamyslet nad obecnou otázkou hledání univerzálního biomarkeru sepse. Zde je v první řadě nutné si připomenout, že sepse vznikla jako koncept, jakýsi umělý konstrukt pro život ohrožující stav vyvolaný odpovědí hostitele na závažnou infekci. Pod jeden pojem tak v klinické praxi zahrnujeme biologicky extrémně heterogenní interakci mezi mnoha různými predátory (patogenem), kořistí (pacientem) a zásahy lékaře. Predátoři, tj. původci infekcí, se značně liší svou schopností a mechanizmy, jak aktivovat imunitní systém. Kořistí, tj. pacientem, může být dosud zcela zdravý, mladý člověk nebo naopak senior s mnoha různě závažnými komorbiditami. Naše léčebné intervence (operační trauma, 
léky, imunosuprese, onkologická léčba apod) samy o sobě významně ovlivňují reakci hostitele na infekci. Míra i charakter hostitelské odpovědi, a tím i biomarkerů, jsou tak ovlivněny mnoha faktory. Dalším problémem při hledání univerzálního biomarkeru sepse je skutečnost, že neexistuje žádný pomyslný, patofyziologicky měřitelný bod zlomu, který by obrannou a reparativní odpověd' organizmu na infekci měnil na nekontrolovatelný, sebezničující proces, označovaný jako sepse. Sepse není fenoménem "vše nebo nic". To samé proto platí i pro biomarkery, včetně presepsinu. Vysoké hodnoty biomarkerů mají jistě svou informační váhu a mohou být důležitým, často jediným varovným signálem, že pacient je více nemocný, než na první dojem klinicky vypadá. Platí však i opačný stav, při kterém má pacient v septickém šoku pouze mírně zvýšené hodnoty konvenčních biomarkerů. Je třeba mít stále na mysli, že na jednu stejnou diagnózu ( $v$ tomto př́padě infekce) může připadat široké rozmezí hodnot biomarkerů. Konečně odpověd' organizmu na jakýkoliv devastující inzult (infekční i neinfekční povahy) je nespecifická, zahrnující stovky společných mediátorů a dílčích molekul. U všech dostupných biomarkerů tak platí, že jedna hodnota může znamenat mnoho možných diagnóz. A zdá se, že ani presepsin nebude $v$ tomto ohledu výjimečný. Recentní práce u pacientů po srdeční zástavě je názorným príkladem, že k jeho zvýšení nedochází pouze u čistě infekčních př́čin imunitní odpovědi [8]. Diagnostická interpretace presepsinu (hodnoty nízké/vysoké, trend rostoucí/klesající) tak vyžaduje stejnou obezřetnost, jako je tomu u CRP i PCT. Zatím metodologicky nejkvalitnější analýza srovnávající diagnostickou přesnost PCT a presepsinu superioritu presepsinu $v$ diagnostice infekce a sepse u kriticky nemocných neprokázala [9].

Z kontextu výše uvedené diskuse plyne, že hledání univerzálního biomarkeru sepse je zřejmě slepá cesta. Naštěstí vstupujeme do období, v němž pomalu opouštíme "geocentrický" model sepse 80.-90. let minulého století, který přinesl téměř 30 let nereprodukovatelných randomizovaných kontrolovaných studií. Kombinace umělé inteligence (big data analýzy) a pokročilých omických metod nám pomalu poodhaluje cestu vpřed a ukazuje na existenci řady odlišných, ale biologických homogenních endotypů, které charakterizují reakci organizmu na infekci $[10,11]$. Je tak pravděpodobné, že se v blízkém budoucnu posuneme od konceptu nespecifické syndromologie (např. sepse, ARDS) k mnohem přesnějším subtypům endogenní (imunitní, metabolické, hormonální) odpovědi na infekci/trauma, pro které budeme mít mnohem specifičtější biomarkery a snad i léčebné intervence, podobně jako tomu již je dnes u některých onkologických diagnóz.

V současné klinické praxi stále platí 3 základní otázky při rutinním vyhodnocení a managementu pacienta s podezřením na infekci [12]:

- má pacient infekci? (klinické projevy infekce?, předpokládaný zdroj?, laboratorní ukazatele?, mikrobiologické výsledky?)
- je infekce závažná? (aktivní posouzení akutní orgánové dysfunkce a dalších varovných známek)

- odpovídá pacient adekvátně na zavedenou léčbu?

Všechny dostupné biomarkery jsou užitečnými, ale vždy jen pomocnými vodítky při hledání odpovědí na položené otázky. Jakkoliv je presepsin zajímavým biomarkerem infekce a ukazatelem závažnosti stavu, i on má zřejmě svých padesát odstínů šedi. Rigorózní vyhodnocení jeho skutečného př́nosu by mělo předcházet implementaci do denní klinické praxe. Tak daleko ale zatím nejsme.

\section{Literatura}

1. Goto T, Yoshida K, Tsugawa $Y$ et al. Infectious Disease-Related Emergency Department Visits of Elderly Adults in the United States, 2011-2012. J Am Geriatr Soc 2016; 64(1): 31-36. Dostupné z DOI: <http://dx.doi.org/10.1111/jgs.13836>.

2. Fleischmann C, Scherag A, Adhikari NK et al. Assessment of Global Incidence and Mortality of Hospital-treated Sepsis. Current Estimates and Limitations. Am J Respir Crit Care Med 2016; 193(3): 259-272. Dostupné z DOI: <http://dx.doi.org/10.1164/rccm.201504-07810C>.

3. Filbin MR, Lynch J, Gillingham TD et al. Presenting Symptoms Independently Predict Mortality in Septic Shock: Importance of a Previously Unmeasured Confounder. Crit Care Med 2018;46(10): 1592-1599. Dostupné z DOI: <http://dx.doi.org/10.1097/CCM.0000000000003260>.

4. Kaukonen KM, Bailey M, Pilcher Det al. Systemic inflammatory response syndrome criteria in defining severe sepsis. N Engl J Med 2015; 372(17): 1629-1638. Dostupné z DOI: <http://dx.doi.org/10.1056/NEJMoa1415236>.

5. Heffner AC, Horton JM, Marchick MR et al. Etiology of illness in patients with severe sepsis admitted to the hospital from the emergency department. Clin Infect Dis 2010; 50(6): 814-820. Dostupné z DOI: <http://dx.doi.org/10.1086/650580>.

6. Káňová $M$, Dobiáš $R$, Liszková $K$ et al. Presepsin $v$ diagnostice sepse. Vnitř lék 2019; 65(7-8): 497-505.

7. Jabor A, Kubíček Z, Labanczová $M$ et al. Presepsin: co je nutné vědět pro korektní interpretaci. Vnitř lék 2019; 65(7-8): 490-496.

8. Qi Z, Zhang Q, Liu B et al. Presepsin As a Biomarker for Evaluating Prognosis and Early Innate Immune Response of Out-of-Hospital Cardiac Arrest Patients After Return of Spontaneous Circulation. Crit Care Med 2019; 47(7): e538-e546. Dostupné z DOI: <http://dx.doi. org/10.1097/CCM.0000000000003764>.

9. Kondo $Y$, Umemura $Y$, Hayashida K et al. Diagnostic value of procalcitonin and presepsin for sepsis in critically ill adult patients: a systematic review and meta-analysis. J Intensive Care 2019; 7: 22. Dostupné z DOI: <http://dx.doi.org/10.1186/s40560-019-0374-4>.

10. Scicluna BP, van Vught LA, Zwinderman AH et al. MARS consortium. Classification of patients with sepsis according to blood genomic endotype: a prospective cohort study. Lancet Respir Med 2017; 5(10): 816-826. Dostupné z DOI: <http://dx.doi.org/10.1016/ S2213-2600(17)30294-1>.

11. Seymour CW, Kennedy JN, Wang S et al. Derivation, Validation, and Potential Treatment Implications of Novel Clinical Phenotypes for Sepsis. JAMA 2019. Dostupné z DOI: <http://dx.doi.org/10.1001/ jama.2019.5791>

12. Horák J, Harazim M, Karvunidis T et al. Sepse - jak ji poznat, na co se zaměřit aneb zpět $k$ základům ve světle nové definice. Vnitř Lék 2016; 62(7-8): 568-574.

\section{prof. MUDr. Martin Matějovič, Ph.D.} $\triangle$ matejovic@fnplzen.cz

I. interní klinika LF UK a FN PIzeň

www.fnplzen.cz

Doručeno do redakce 10. 6. 2019 